\title{
The Dynamic of Consumer Behavior, Consumer Decision, Consumer Satisfaction on Consumer Loyality on Sipirock Coffee Jakarta
}

\author{
Dr. Wier Ritonga \\ Sekolah Tinggi Ilmu Ekonomi Pengembangan \\ Bisnis Dan Kewirausahaan, Jakarta \\ Dr. Machmed Tun Ganyang \\ Sekolah Tinggi Ilmu Ekonomi Pengembangan \\ Bisnis Dan Kewirausahaan, Jakarta
}

\begin{abstract}
The reasearch aim to determine the dynamic of of Consumer Behavior, Consumer Decision, Consumer Satisfaction on Consumer Loyality on Sipirock Coffee Jakarta, the year of 2017. Many prior researchs have done by some researchers, but this research differ to prior researchs, since this research done on an etnic coffee shop that serve not only coffe but also the food related to the etnic of southern Tapanuli in North Sumatera. Beside that, the coffee shop also hold etnic live music every Friday and Saturday night, one of The culture of Batak people is sing and dancing (manortor). In this coffe shop the customer feel closed to one another as they have the same culture. For the international community, it can be used to learn about Indonesia, specially the culture of the people of north sumatera. Indonesia consist of five big islans (Sumatera, Java, Borneo, Sulawesi and Papua) and thousand small islands. Any region in North Sumatera have their own coffee, for instance Mandailing coffee, Sidikalang coffee and Sipirok coffee. The management of the coffee shop mix ethnic and modern concepts by providing wi-fi connection. Simple random sampling used in the research and quatitative aproach. Collecting data used questioner and direct observation. The population of the research is all the consumer of the coffee shop, with purpossive sampling, and the sampel is 133 (one hundred thirty three). The result of the research, (1) consumer behavior has a significant impact on consumer loyality; (2) consumer decision to purchase has a significant impact on consumer loyality; (3) consumer satisfaction has a significant impact on consumer loyality; (4) consumer behavir has a significant impact on consumer satisfaction; (5) consumer decision to purchase has a significant impact on consumer satisfaction.
\end{abstract}

Key words: Consumer Behavior, Consumer Decision, Consumer Satisfaction, Consumer Loyality

\section{Background}

\section{INTRODUCTION}

As the development in digital technology, which is give wide opportunity to consumer to know all about the product delivered by a company. The marketer should focus their effort to influuence the consumer behavior, consumer decision, consumer satisfaction and consumer loyality, in order to keep maintaint the competitiveness. All the consumer in their live face the rapid change, for example the change from traditional life style to modern life style, as the impact of the globalization occured. As the increasing of the income of society caused linearly increasing of the needs and wants. In the other word the increasing of the society's income lead to the luxury life style, modern life style that suitable for the community. For instant, the increasing of the income of community came from Southern Tapanuli, North Sumatera, rise the need for gathering in a resto or coffee shop with the atsmosphere suitable for the community. 
Realize the needs of the community, the owner of the coffe shop try to accomodate by open the coffe shop that suitable to the community and the other community. The unique concept of the management is mix ethnic and modern. In this resto, management provide wi-fi connection, that made the costumers feel comfortable to waist their spare time in it. Any region in North Sumatera have their own coffee, such as Mandailing coffee, Sidikalang coffee and Sipirok coffee. This resto offer not only ethnic coffee of North Sumatera, but also offer coffee of over the world. The resto is differ to the other one such as Starbuck, Kopitian, etc, since the mixing of ethnic and modern concept of the management. The customer of the resto can be classified as north sumatera community and out side North Sumatera community, including international community. The positition of the resto in southern of Jakarta,jalan T.B. Simatupang, Tanjung Barat, where many expatriate have their office aroud also made this resto one of the favourite coffee shop. The coffee shop not only serve coffee and another beverage, but also serve complete food menu of souther Tapanuli, North Sumatera.

As one of the part of the culture of the peoples from North Sumatera are singing and dancing. To accommodate the part of culture the management serve the live etnic music from every Friday and Saturday night. So, for the foreigner, the atmosfer of the resto and the culture of the customer of North Sumatera community can be used to learn the culture of Indonesia, specially North Sumatera. The matter when Friday and Saturday is the parking space. Friday night and Saturday night normally fully booked by the customer, since the other night looked quiet. There is a big different of amount of the consumer who visit the coffee shop between on Sunday up to Thursday with who visit the coffee shop on Friday up to Sunday. It needed a study of the consumer behavior that effect the customer loyality. There is no study before how consumer behavior influence the consumer decision, the consumer decision influence consumer satisfaction, consumer satisfaction influence consumer loyality of the coffe shop, though it's very important to know in order to know the needs of the consumer. Therefore, this research aim to determine the influence of consumer behavior on consumer decision to purchase, the influence of consumer decision to purchase on consumer satisfaction, and the influence of consumer satisfaction on loyality.

\section{REVIEW OF THE LITERATURE}

Several sense of Marketing management acording to Philip William J. Shultz. Buchari Alma $(2005 ; 103)$ Marketing management is avtivities cover planning of the marketing, directing, controlling the whole marketing of the company or marketing of a aprt of the company. This sense view marketing management as an activity related to planning, directing, controlling of the company's marketing. As Stanton (2001: 7), said that marketing as a whole system of busines activities that addressed to plan, etermining the price, to promote the product, to distribute the product and service either to the existing buyer or potential buyer. Many organizations are still under high risk marketing as they are not very much aware about whom their customers are and this implies that they have no real idea who they are trying to target (Rawal, P, Upadhayay, :2017:21-27), so the marketing plan should mention clearly the marketing target.

From those senses, can be concluded that marketing is a comprehensive effort to join strategic plans that directed to the effort to satisfy the consumer need and want to get the gain from the exchange or transaction.

Some sense regarding consumer behavior according to Shiffman and Kanuk (2005: 83) said, Consumer behavior can be defined as the behavior that customer display in searching , purchasing, using, evaluating, and disposing of products, services, and ideas they expect will satisfy their needs. This opinion means behavior that consumer the activities for searching, 
buying, using, evaluating product, service, idea that expected to satisfy the consumer needs by consume the products and services offerred.

Meanwhile Hawkins, Best and Coney (2007: 54) said that consumer behavior is a study about how people, group or organization do the process of selecting, pacification, utility and stop to satisfy the consumer need by consume the products or services. This sense give the pressure of the procees how the consumer get satisfaction by consume the products and services. According to Peter dan Olson (2005: 44) said the the consumer behavior as a dynamic interaction of the effect and awareness, behavior and environment where people do exchange on their life aspec. This sense view the consumer behavior as a dynamic interaction in the exchange. Based on Blackwell et. al. In Blythe (2013:5), consumer behavior is the activities people undertake when obtaining, consuming and disposing of products and services. This opinion said that consumer behavior is activities that people done to get, to consume, and to compose a product or service. The pressure of this opinion is a process to get, to use, to compose a product or service. Opinion by Hawkins, et. al, (2004:7), the field of consumer behavior is the study of iundividuals, group or organization and the processes they use to select, secure and dispose of the products and services, experiences, or ideas to satisfy needs and the impact that these processes have on the consumer and society. This view of consumer behavior is broader than the traditional one, which focuse more on the buyer and immediate antecedents and consequences of the purchasing process. This sense containing more wide understanding of consumer behavior. The important to learn consumer behavior as proposed by Blythe (2013:7), the fundamental basis for marketing thinking is that the customer (or consumer) should be at the centre of everything the firm does. It means that an understanding of how and why people make purchasing decision is crusial to formulate a marketing plan. This sense said the important to learn consumer behavior because is a fundamental or basic of the marketing thinking that should placed in the centre all the activities of the company. Consumer behavior based on Setiadi (2005: 3) is dynamic, means consumer behavior always change all the time, that's why the marketer should focus on it. Kotler and Amstrong in Sudaryono (2016:67), said consumer behavior is evaluation of feel and tendention of people that consistantly like or dislike an object or idea. This opinion give a pressure to the feeling and tendentiom of the people..

From all of those senses, opinons, can be syntesize that consumer behavior is activity that people done to get, to consume, to compose that based on want, feeling, tendention of people dynamicly that like or dislike an object that can satisfy consumer need. It means, consumer behavior can be changed dynamicly. Based on Kotler and Keller(2008:166) Consumer behavior can be affected by some factors, such as (1) Culture; (2) Sub Culture; (3) Social Classification; (4) Reference group; (5) Family; (6) Personality; (7) Psychologies. Consumer decision as a indiviadual activity that directly involved on decision making to purchase product offerred by saler. The definition of purchase desion by consumer based on Kotler and Amstrong (2006:226) is a step in consumer decision to purchase. According to Schiffman dan Kanuk (2006: 547) consumer decison is choosing among two or more option alternative decision to purchase. It means someone able to make decision, It means should available some options. There are three activities that happened in consumer decision according to Hahn (2006:69), such as (1)Routinity of consumer doing purchase; (2) Quality was receipt in consumer decision to purchase; (3) Commitment or loyality of the consumer that usually bought the competitoor's product. Consumer decision making process, consist of (1) Problem recognizing; (2) Information searching; (3) Consumer decision to purchase alternative evaluation and consumer after purchase behavior. The things should be done by marketer is to understand the consumer behavior in any step and what impact that worked on each step. The satisfed 
consumer will keep do repurchase, and those who was not satisfied will stop their purchase of the product and possible they will share the information within their relative and friends. Consumer decisions are affected from personal characteristics, like age (Kotler in Papafotikas,L, Dimitrios Chatzoudes, D, Kamenidou, I: 2014:456-465). Age is related to the life style., different age caused different need of someone. Purchase intentions considered very important by scholars because it's very important to identify consumer purchase behavior (Mehmood, Shafiq, 0: 2015), consumer purchase behavior will influence purchase decision of the consumer.

From Some senses or definition expressed above, so it can concluded that consumer decision to purchase is selecting among two or more decision option to purchase, which consumer do purchase to satisfy the consumer need, that can be measured by (1) Problem recognizing; (2) Information Searching; (3) Alternative evaluation; (4) Dedcision to purchase; (5) Consumer after purchase behavior.

Customer satisfaction has often been quoted as the most obvious antecedent of customer loyalty (Alegre and Cladera, in Srivastava (2018:1). After consumer purchase a product or service, then consumer consume the product or service. Feeling can be differed based on size, that can be positive or negative feeling. Based on Blackwell, et. al. (2006:203), ideally, companies want their products to provide as much reinforcement as possibble. Doing so means that customers are much more likely to become repeat buyers. Unfortunately, consumption experiences sometimes bring punishment. Punishment occurs when consumption leads to negative outcomes. That's why the marketer should focus on effort how to make the consumer feel positif after consume the product or service sold. Sense of Blackwell, et. al,(2006:222), determinants of satisfaction focus on three major determinants, such as, product performance, consumption feelings and expectation. The company should pay attention on these three determinants of satisfaction..

Based on Z, Ahmad (2009:143) said that based on finding by Tse dan Wilton the formula of consumer satisfaction, as follows :

\section{Consumer Satisfaction $=\mathbf{f}($ expactation, perceived performance)}

From the formula above there are two main variables that influence the consumer satisfaction, such as Expectation Perceived performance. If Perceived Performance more than expectation so the consumer will satisfy. One thing that important to pay attention that consumer satisfaction is a long term strategy that need commitment, either regarding fund needed or to increase consumer/customer satisfaction. Based on A, Zein (2009:143) there are six important aspecs consumer complain handling, such as (1) Empathy on angry cunsumer; (2) Speed on complain handling; (3) Fairness on complain handling; (4) Easy to contact by consumer; (5)Increase performance strategy;(6) Implement Quality function depkoyment (QFD), practice to design a process as a response on customer need. Satisfaction will rise customer loyality. Customer loyality as endogenous variable caused by combination of satisfaction, switching barrier of vendor, and customer complain. Loyality can be formulated as follows :

\section{Loyality = $\mathbf{f}$ (customer satisfaction, switching barrier, voice)}

From some senses have been expressed above, can be conclude that Consumer satisfaction is fullfillment of consumer/customer expectation and perceived performance of products purchased by consumer/customer. If Perceived Performance more than expectation, so that consumer/customer will satify.Consumer satisfaction can be measured expectation and perceived performance. 
Customer loyalty plays a very important role to achieve competitive advantage and maintain it (Bagram, M, M, M, Khan, S : 2012). Marketer should keep maintaint the loyality of the costumer by considering the consumer satisfaction.

\section{Purposes of the research}

The purposes of the research, such as. (1) To determine the impact of consumer behavior on consumer loyality (2) To determine the impact of consumer decision to purchase on consumer loyality; (3) To determine the impact of consumer satisfaction on consumer loyality; (4) To determine the impact of consumer behavior on consumer satisfaction; (5) To determine the impact of consumer decision to purchase on consumer satisfaction.

\section{Design and Research Framework}

\section{RESEARCH METHOD}

This reasearch uses descriptive and quantitative approach, by describing the state of the object when the research conducted. The study eximine the impact of four variables,three independent variables, such as (1)consumer behavior $\left(\mathrm{X}_{1}\right)$; $(2)$ consumer decision $\left(\mathrm{X}_{2}\right)$; (3) consumer satisfaction $\left(\mathrm{X}_{3}\right)$ and one dependent variable,namely Consumer loyality (Y). Loyality is measured by the willingness of the consumer to do repurchase and the availability of the consumer to give recommendation to the potential consumer. Previous research done by some researchers show (1) There is a positive and significant impact of consumer behavior on consumer loyality; (2) There is a positive and significant impact of consumer decision to purchase on consumer loyality; (3) There is apositive and significant impact of consumer satisfaction on consumer loyality; (4) There is a positive and significant impact of consumer behavior $n$ on consumer satisfaction;(5) There is a positive and significant impact of consumer decision to purchase on consumer satisfaction.

Commonly this research is aimed to analyze the impact the independent varibles on consumer/customer loyality at Sipirock Coffee, Jakarta, as shown at the matrix correlation as shown at figure 1. Research frame work, as follows :

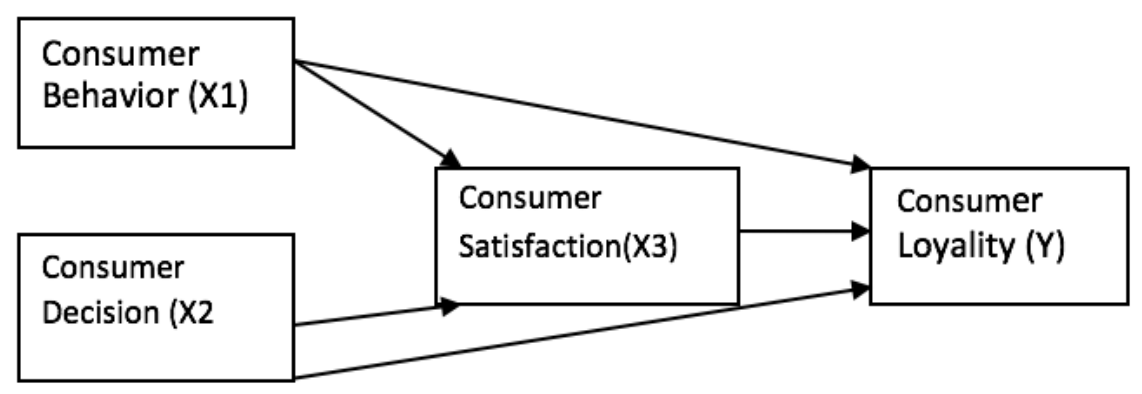

Figure 1 :Research Framework.

This research uses three independent variables, such as (1) Consumer behavior; (2) consumer decision to purchase; (3) consumer satisfaction, and one depenedent varible, namely Consumer loyality, which is express the willingness of the consumer to do repurchase after have satisfaction on consuming the product purchased, and avaibility of the consumer to give recommendation to the potential consumer.

\section{Population and Sample}

Population means as an area of generalitation that consits of object that has the quality and characteristic that applied by reseracher to study and than conclude it. The population of this 
research is all the consumer of Sipirock Coffee, which is unknown. This research use purpossive sampling and the sample is 133 consumers.

\section{Hypothesis}

This research use hypothesis as follows (1) suspected thre is a positive and significant impact of consumer behavior on consumer loyality; (2) Suspected there is a posisitve and significant impact of consumer decision to purchase on consumer loyality; (3) Suspected there is a positive and significant of consumer satisfaction on consumer loyality; (4) Suspected there is a positive and significant impact of consumer behavior on consumer satisfaction; (5) Suspected there is a positive and significant impact of consumer decision to purchase on consumer satisfaction.

The whole hypothesis above reflected in the statistical hypothesis such as (1) Ho : There is no positive and significant impact of consumer behavior on consumer loyality, H1 : There is a positive and significant impact of consumer behavior on consumer loyality; (2) Ho : There is no positive and significant impact of consumer decision to purchase on consumer loyality, H1 : There is a positive and significant impact of consumer decision to purchase on consumer loyality; (3) Ho : There is no positive and significant impact of consumer satisfaction on consumer loyality, $\mathrm{H} 1$ : There is a positive and significant impact of consumer satisfaction on consumer loyality; (4) Ho : There is no positive and significant impact of consumer behavior on consumer satisfaction, $\mathrm{H} 1$ : There is a positive and significant impact of consumer behavior on consumer satisfaction; (5) Ho : There is no positive and significant impact of consumer decision to purchase on consumer satisfaction, $\mathrm{H} 1$ : There is a positive and significant impact of consumer decision to purhase on consumer satisfaction.

\section{Place and Time of The Research}

The research was conducted in Sipirock Coffee, Jl. T.B. Simatupang, Tanjung Barat, Jakarta Selatan, from July 2017 until July 2018.

\section{Respondent Profile}

\section{DISCUSSION}

Result of research survey have done within seventy nine cunsomer of Sipirock coffee, find out the profile of the respondent as stated on table 1, respondent characteristic as follows :

Table 1, Respondent Characteristic

\begin{tabular}{|c|c|c|}
\hline Criteria & Amount & Persentage \\
\hline \multicolumn{3}{|l|}{ Gender } \\
\hline 1. Woman & 73 & $55 \%$ \\
\hline 2. Man & 60 & $45 \%$ \\
\hline Total & 133 & $100 \%$ \\
\hline \multicolumn{3}{|l|}{ Age } \\
\hline 1. 20-30 Years old & 63 & $47.3 \%$ \\
\hline 2. More than 31 Years Old & 70 & $52.7 \%$ \\
\hline Total & 133 & $100 \%$ \\
\hline \multicolumn{3}{|l|}{ Marrital Status } \\
\hline 1. Married & 101 & $76 \%$ \\
\hline 2. Single & 32 & $24 \%$ \\
\hline Total & 133 & $100 \%$ \\
\hline \multicolumn{3}{|l|}{ Education Back Ground } \\
\hline 1. Senior High School & 15 & $11 \%$ \\
\hline $\begin{array}{ll}\text { 2. } & \text { Diploma }\end{array}$ & 0 & $0 \%$ \\
\hline 3. Bachelor & 85 & $64 \%$ \\
\hline 4. Master & 33 & $25 \%$ \\
\hline Total & 133 & $100 \%$ \\
\hline
\end{tabular}


Based on the data stated on the table above, the amount of respondent dominated by woman, amounted 73 (seventy three), the different of that amount caused by usually the women respondent visited the Sipirock Coffe grouply. In term of age, respondent dominated by respondent above thirty one years old, amounted 70 (seventy). In the view point of education back ground, find out that bachelor is the biggest amount, amounted 85 (eighty five) follow by respondent with master degree, and in term of marrital status, someone who has married with brought the family is the biggest amount of the respondent.

\section{DISCUSSION}

Based on the result of the normality test, can be concluded that pathway of relation is normal pathway so that it's eligible to be used by research hypothesis test with path analysis model, as shown in table 2 Summary of estimated error calculation result normality :

Table 2 Summary of Estimated Error Calculation Result Normality

\begin{tabular}{|l|l|c|c|l|}
\hline No & \multicolumn{1}{|c|}{ Variable } & $\rho$-value & $\alpha$ & \multicolumn{1}{|c|}{ Conclusion } \\
\hline 1 & Consumer Behavior & 0.091 & 0.05 & Normal \\
\hline 2 & Consumer Decision to Purchase & 0.418 & 0.05 & Normal \\
\hline 3 & Consumer Satisfaction & 0.117 & 0.05 & Normal \\
\hline 4 & Consumer loyality & 0.246 & 0.05 & Normal \\
\hline
\end{tabular}

To find out significant and linear correlation and the respective variables of the research, the researcher condoct significance and linearity test. Based on the result of the test ( significance and linearity test) with F test technique as stated in the table 3. Summary of Test Result Significance regression equation, as follows :

Table 3. Summary of Test Result Significance regression equation

\begin{tabular}{|c|c|c|c|c|c|c|c|}
\hline \multirow[t]{3}{*}{ Variable } & \multicolumn{4}{|c|}{ Significance Test } & \multicolumn{3}{|c|}{ Linearity } \\
\hline & \multirow[t]{2}{*}{$\mathrm{F}_{\text {Count }}$} & \multicolumn{2}{|c|}{$\mathrm{F}_{\text {Table }}$} & \multirow[t]{2}{*}{ Status } & \multirow[t]{2}{*}{$F_{\text {Count }}$} & \multirow{2}{*}{$\begin{array}{l}F_{\text {Table }} \\
(0,05)\end{array}$} & \multirow[t]{2}{*}{ Status } \\
\hline & & $\alpha=0,05$ & $\alpha=0,01$ & & & & \\
\hline Y on $\mathrm{X}_{1}$ & 26.762 & 3,94 & 6,9 & Significance & $1,568 \mathrm{~ns}$ & 1,61 & Linear \\
\hline$Y$ on $X_{2}$ & 48,148 & 3,94 & 6,9 & Significance & $1,099 \mathrm{~ns}$ & 1,61 & Linear \\
\hline Y on $X_{3}$ & 46,492 & 3,94 & 6,9 & Significance & $1,252 \mathrm{~ns}$ & 1,61 & Linear \\
\hline $\mathrm{X}_{3}$ on $\mathrm{X}_{1}$ & 55,561 & 3,94 & 6,9 & Significance & $1,403 \mathrm{~ns}$ & 1,61 & Linear \\
\hline $\mathrm{X}_{2}$ on $\mathrm{X}_{1}$ & 151,386 & 3,94 & 6,9 & Significance & $1,227 \mathrm{~ns}$ & 1,61 & Linear \\
\hline
\end{tabular}

Based on result of significance test and linearity regression equation on the pathway of that relationship, can be concluded that path way is very significant and linear, thus eligible to used by research hypothesis testing with path analysis model, as shown by table 4 Summary of Result of Hypothesis testing effect consumer behavior, consumer decision to purchase, consumer satisfaction on consumer loyality of Sipirock Coffee Jakarta.:

Table 4 Summary Of Result Of Hypothesis Testing Effect Consumer Behavior, Consumer Decision To Purchase, Consumer Satisfaction On Consumer Loyality Of Sipirock Coffee Jakarta.

\begin{tabular}{|l|l|l|l|l|l|l|}
\hline No & Hypothesis & Path Coefficient & \multirow{2}{*}{$\mathrm{t}_{\text {Count }}$} & $\mathrm{t}_{\text {Table }}$ & Conclusion \\
\cline { 4 - 6 } & & & & 0.05 & 0.01 & Significance \\
\hline 1 & $\mathrm{X} 1$ on $\mathrm{Y}$ & 0,265 & 2,738 & 1,979 & 2,356 & Significance \\
\hline 2 & $\mathrm{X} 2$ on $\mathrm{Y}$ & 0,242 & 2,478 & 1,979 & 2,356 & Significance \\
\hline 3 & $\mathrm{X} 3$ on $\mathrm{Y}$ & 0,278 & 2,363 & 1,979 & 2,356 & Significance \\
\hline 4 & X1 on X3 & 0,253 & 3,059 & 1,979 & 2,356 & Significance \\
\hline 5 & X2 on X3 & 0247 & 2,630 & 1,979 & 2,356 & Significance \\
\hline
\end{tabular}


Hypothesis test done after the various tests required on the data obtained, then the next step is to test the hypothesis. The hypothesis that will be tested is the impact of independent variables on dependent variable.The model impact of the dependent variable is analyzed based on the understanding of theoritical concept. After calculation using SPSS, based on path analysis, it's known that (1) The first there is a positive and significant impact of consumer behavior on consumer loyatity. Therefore, it can be conclude that consumer loyality can be affected by variance of consumer behavior. It's found that the figure or value of path coefficient is 2.65 with $t$ count of 2.7381 is greater than the value of $t$ table $u \operatorname{sing} \alpha=0,05$ is 1.979.The result of the analysis hypothesis provides finding that the consumer behavior influences on consumer loyality. The finding in line with previous research conducted by Adunola, et al (2016:43-52)), that said consumer behavior has a positive and significant impact on consumer loyality. It's means that if the company want to inrease consumer loyality, shold pay attention on consumer behavior; (2)The second, result of the hypothesis analysis provides a finding that consumer decision to purchase has a positive and significant impact on consumer loyality. It's found that the value of path coefficient is 0.242 as $t_{\text {count }}$ amounted to 2.478 greater than the value of $t_{\text {table }}$ using $\alpha=0.05$ at 1.979 . The finding is in line with previous reseacrh conducted by Petterson and Soderstrom (2015:30), that conclude consumer decision to purchase has a positive and significant impact on consumer loyality. It's means the company should pay attention on consumer decision to purchase in oder to increase consumer loyality; (3)The third, result of the hypothesis analysis, provides finding that consumer satisfaction has a positive and significant impact on consumer loyality, it's shown by the value of path coefficient is 0.278 , as $t$ count 2.363 which is greater than the value of $t$ table using $\alpha=0.05$ at 1.979 . The finding implication that the company can inrease the consumer loyality through consumer satisfaction; (4) The fourth, result of hypothesis analysis, provide result that consdumer behavior has a positive and significant impact on consumer satisfaction, which is shown by the value of path coefficient amounted to 0.253 as $t_{\text {count }} 3.059$ is greater than the value of $t$ table using $\alpha=0.05$ at 1.979. The finding is in line with previous research conducted by Irmanda (2016) that said there is a positive and significant impact of consumer behavior on consumer satisfaction. This finding provide implication that consumer behavior can be used to increase consumer satisfaction; (5) The fifth, result of the hypothesis analysis, provide that consumer decison to purchas has a positive and significant impact on consumer satisfaction, It's shown by the path coefficient is 0.247 , with $t_{\text {count }} 3.630$ is greater than the value of $t_{\text {table }}$ using $\alpha=0.05$ amounted to 1.979. The finding is in line with previous research conducted byMagenta (2015) that said consumer decision to purchase has a positive and significant impact on consumer satisfaction. Thus, it's can be said that consumer satisfaction can be enhance when it's supported by consumer decision to purchase.

\section{CONCLUSION}

Based on the hypothesis test that discussed the result of the research as describe above, it can be concluded, such as (1)There is a positive and significant impact of consumer behavior on consumer loyality; (2) There is a positive and significant impact of consumer decision to purchase on consumer loyality; (3) There is a positive and significant impact of consumer satisfaction on consumer loyality; (4) There is a positive and significant impact of consumer behavior on consumer satisfaction; (5) There is a positive and significant impact of consumer decision to purchase on consumer satisfaction.

\section{Reference}

A, Buchari, (2009). Manajemen Bisnis Syariah. Jakarta: ABT.

A, Jaenudin,(2014). Aplikasi Salesmanship. Jakarta: PT. Gramedia

Bagram, M, M, M, Khan, S (2012) Attaining Customer Loyalty! The Role of Consumer Attitude and Consumer Behavior, International R eview of Management and Business Research, Vol. 1 Issue.1 
Ritonga, W., \& Ganyang, M. T. (2019). The Dynamic of Consumer Behavior, Consumer Decision, Consumer Satisfaction on Consumer Loyality on Sipirock Coffee Jakarta. Archives of Business Research, 7(12), 332-340.

Blackwell, R,D, et. al,(2006), Consumer Behavior. Mason: Thomson Higher Education.

Blythe, J, (2013). Consumer Behavior. Singapore: Sage Publication Asia-Pasific Pte Ltd.

DH, Basuswasta,(2010). Manajemen Pemasaran-Analisis Perilaku Konsumen. Yogyakarta: Liberty.

Dimitrios Chatzoudes, D, Kamenidou, I: (2014) Purchase decisions of Greek consumrs: an empirical study, Procedia Economics and Finance 9 (2014) 456 - 465.

Hamzah, Y, (2015),Pengaruh Perilaku Konsumen, Kinerja Karyawan, Kualitas Pelayanan terhadap Kepuasan Pelanggan,Fakultas Ekonomi dan Bisnis Universitas Islam Negeri Syarif Hidayatullah, Jakarta. 2015, http://repository.uinjkt.ac.id/dspace/handle/123456789/3480

Hawkins, D, I, et. al.(2004), Cosumer Behavior Building Marketing Strategy, New York: McGraw-Hill/Irwin. Irmanda, A, (2016). Pengaruh Perilaku Konsumen Yang Dimediasi Oleh Kepuasan Pelanggan Jasa Penggiriman Jalur Darat JNE Cabang Hijrah Sagan Yogyakarta Fakultas Ekonomi Universitas Negeri Yogyakarta,. Jurnal manajemen Bisnis Indonesia,Vol 5 No. 6. http://journal.student.uny.ac.id/ojs/index.php/jmbi/article/view/5065.

Kotler, P, Keller(2009), Manajemen Pemasaran dan Pemasaran Jasa, Bandung : Alfabeta

Kotler, P., Lane, K, .(2009). Manajemen Pemasaran, edisi 13. Jakarta : Erlangga.

Kotler, P, (2006), Manjemen Pemasaran, Jakarta : Erlangga.

Lupiyoadi, H.(2009). Manajemen Pemasaran Jasa. Jakarta : Erlangga.

Magenta, D, (2015), Pengaruh Perilkaku Konsumen, Keputusan Pemebelian terhadap Kepuasan Pelanggan.

Fakultas Ekonomi Universitas Diponegoro. Jurnal Administrasi Bisnis Universitas Diponegoro.

https://ejournal3.undip.ac.id/index.php/jiab/article.../8932/8682.

Mehmood, W, Shafiq,0,( 2015) Impact of Customer Satisfaction, Service Quality,Brand Image on Purchase Intention, journal of marketing and consumer research, Vol.15, 2015

Mc. Carthy . E, Jerome.(2009). Dasar-dasar Pemasaran, Surabaya: Erlangga.

Nitisemito,A. S.(2009). Marketing. Jakarta : Ghalia Indonesia.

Okei, A, 0, et al., on International Review of Management and Marketing ISSN: 2146-4405, available at http: www.econjournals.com, International Review of Management and Marketing, 2016, 6(S4) 43-52. Special Issue for "Asia International Conference (AIC 2015), 5.

Peter, J, P, Olsen, J, C, (2005), Perilaku Konsumen dan Strategi Pemasaran, Jakarta : Salemba Empat.

Pettersson, C, Soderstrom, B, Bieden, G. (2015). Umeå School of Business, and Economics, Spring Semester. [online]. https://www.diva-portal.org/smash/get/diva2:827720/FULLTEXT01.pdf.

Rangkuti F.(2009).Riset Pemasaran. Jakarta. : PT. Gramedia Pustaka Utama.

Rawal, P, Upadhayay, S, (2017), Understanding Consumer Behaviour and Impact of Integrated Marketing Communication on Decision Making", International Journal of Current Researchand Modern Education, Volume 2, Issue 2, Page Number 21-27, 2017.

Srivastava, M, (2018) Customer satisfaction has often been quoted as the most obvious antecedent of customer loyalty (Alegre and Cladera, IMJ, Vol 7, Issue 1

Setiadi, (2005), Perilaku Konsumen, Jakarta : PT. Gramedia Pustaka Utama.

Schiffman, L, G, Kanuk, L, Z, (2004), Consumer Behavior. New Jersey: Pearson Education Limited.

Sumarwan, Ujang, (2003), Perilaku Konsumen : Teori dan Penerapannya Dalam Pemasaran, Bogor : P. T. Ghalia Indonesia.

Stanton, W., J.(2009). Prinsip-prinsip Pemasaran. Jakarta : Ghalia Indonesia

Sudaryono, (2016), Perilaku Konsumen Dalam Perspektif Pemasaran, Jakarta : Lentera Ilmu Cendikia.

Supriyanto. (2009). Metodologi Riset Bisnis. Jakarta : PT. Indeks.

Wahyuningsih. (2010). Customer Value, Satisfaction and Behavioral Intentions: the Effects of Consumer Search Behavior. [online]. https://www.scribd.com/doc/34140568/Thesis-Consumer-Behavior

Wijayanto, (2005), Pengantar Manajemen, Jakarta : PT. Gramedia Pustaka Utama 